\title{
Development and Rheological Evaluation of DEET (N,N-DiethyL-3-Methylbenzamide) Microparticles Loaded Hydrogel For Topical Application
}

\author{
Topikal Uygulama İçin DEET (N,N-Dietil-3-Metilbenzamid) Mikropartikül \\ Yüklenmiş Hidrojel Geliştirilmesi ve Reolojik Değerlendirilmesi
}

\author{
(D) Rajesh SREEDHARAN NAIR ${ }^{1 *}$, (D) Habibur RAHMAN², (D) Min Xian KONG², (D) Xin Yi TAN², (D) Kah Yin CHEN², (D) Suresh SHANMUGHAM³ \\ ${ }^{1}$ Monash University Malaysia, School of Pharmacy, Department of Pharmaceutics, Selangor, Malaysia \\ 2UCSI University, Faculty of Pharmaceutical Sciences, Department of Pharmaceutical Technology, Kuala Lumpur, Malaysia \\ 3International Medical University, School of Pharmacy, Department of Pharmacy Practice, Kuala Lumpur, Malaysia
}

\begin{abstract}
Objectives: N,N-Diethyl-3-methylbenzamide (DEET) is a broad-spectrum insect repellent that can easily permeate through the skin and can cause undesirable effects, especially in children and pregnant women. The objective of this research was to formulate and evaluate DEET-encapsulated microparticles containing a hydrogel designed to reduce skin permeation and prolong drug release.

Materials and Methods: The formulation design was based on the independent formulation variables of the concentration of chitosan and sodium tripolyphosphate using a simple factorial design experiment. DEET-loaded microparticles were developed and incorporated into a hydrogel. The size of the microparticles was analyzed using the Zetasizer $\mathrm{Nano}^{\circledR}$ particle size analyzer, and the surface morphology, using field emission scanning electron microscopy. Drug release from the microparticles was determined by the dialysis bag method. A rheological evaluation of the formulated gel was performed using a Thermo Haake Rheometer. The in vitro permeation of the formulation was performed using a synthetic Strat-M ${ }^{\circledR}$ membrane.

Results: The size of the microparticles ranged from 0.45 to $8.3 \mu \mathrm{m}$, and the encapsulation efficiencies were $>50 \%$ for all the formulations. The drugrelease curves showed no initial burst release from the microparticle formulation. Instead, a slow and controlled drug release was observed over 24 hours that followed Higuchi kinetics. The cumulative amount of DEET permeated (over $24 \mathrm{~h}$ ) from the DEET solution (control), and the formulation was $211.6 \pm 19.5 \mu \mathrm{g} / \mathrm{cm}^{2}$ and $4.07 \pm 0.08 \mu \mathrm{g} / \mathrm{cm}^{2}$, respectively.

Conclusion: A significantly low DEET permeation from the microparticle formulations indicated minimal absorption of the drug into the body and thus, reduced systemic toxicity. Thixotropic evaluation of the hydrogel formulation demonstrated a hysteresis loop that fitted closely to the Herschel-Bulkley rheological model, ensuring an effortless application and prolonged retention on the skin. Hence, it can be concluded that the developed formulation is an effective delivery approach for controlled insect repellent activity with reduced skin absorption.
\end{abstract}

Key words: Transdermal, DEET, microparticles, permeation, hydrogel

ÖZ

Amaç: N, N-Dietil-3-metilbenzamid (DEET), özellikle çocuklarda ve hamile kadınlarda deride kolaylıkla nüfuz edebilen ve istenmeyen etkilere neden olabilen geniş spektrumlu bir böcek kovucudur. Bu araştırmanın amacı, deri nüfuzunu azaltmak ve ilaç salınımını uzatmak için tasarlanmış bir hidrojel içeren DEET kapsüllü mikropartikülleri formüle etmek ve değerlendirmektir.

Gereç ve Yöntemler: Formülasyon tasarımı, basit bir faktöriyel tasarım deneyi kullanılarak kitosan ve sodyum tripolifosfat konsantrasyonunun bağımsız formülasyon değișkenlerine dayanıyordu. DEET yüklü mikropartiküller geliştirildi ve bir hidrojele disperse edildi. Mikropartiküllerin boyutu, Zetasizer $\mathrm{Nano}^{\circledR}$ partikül boyutu analizörü ve alan emisyonu taramalı elektron mikroskobu kullanılarak yüzey morfolojisi kullanılarak analiz edildi. Mikropartiküllerden ilaç salımı, diyaliz torbası yöntemi ile belirlendi. Formüle edilmiş jelin reolojik bir değerlendirmesi, bir Thermo Haake Reometre kullanılarak gerçekleştirildi. Formülasyonun in vitro geçirgenliği, sentetik bir Strat-M ${ }^{\circledR}$ membran kullanılarak gerçekleştirildi.

Bulgular: Mikropartiküllerin boyutu 0,45 ile 8,3 $\mu \mathrm{m}$ arasında değişiyordu ve enkapsülasyon etkinliği tüm formülasyonlar için >\%50 olarak tespit edildi. İlaç salım profilleri, mikropartikül formülasyonundan ilk patlama etkisi göstermedi. Bunun yerine, Higuchi kinetiğini izleyen 24 saat içinde

*Correspondence: rajeshsreedharan.nair@monash.edu, Phone: +60173397121, ORCID-ID: orcid.org/0000-0002-8540-5044

Received: 29.06.2020, Accepted: 28.08.2020

Turk J Pharm Sci, Published by Galenos Publishing House. 
yavaş ve kontrollü bir ilaç salımı gözlemlendi. DEET solüsyonundan (kontrol) geçirilen kümülatif DEET miktarı (24 saatin üzerinde) ve formülasyon

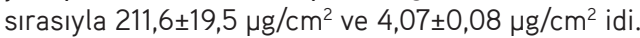

Sonuç: Mikropartikül formülasyonlarından önemli ölçüde düșük bir DEET geçirgenliği, ilacın vücuda minimal absorpsiyonu ve dolayısıyla sistemik toksisitenin azaldığı tespit edildi. Hidrojel formülasyonunun tiksotropik değerlendirmesi, Herschel-Bulkley reolojik modeline yakından uyan, kolay uygulama ve deride uzun süreli tutunma sağlayan bir histerezis döngüsü gösterdi. Bu nedenle, geliștirilen formülasyonun, azaltılmıș deri absorpsiyonu ile kontrollü böcek kovucu aktivite için etkili bir uygulama yaklaşımı olduğu sonucuna varılabilir.

Anahtar kelimeler: Transdermal, DEET, mikropartiküller, nüfuz etme, hidrojel

\section{INTRODUCTION}

N,N-Diethyl-3-methylbenzamide (DEET) is a well-known broadspectrum insect repellent that has been shown to be effective against a variety of insects, including mosquitos, bugs, and mites. 'The unique odor of this insect repellent allows it to act from a certain distance, not too far from the applied surface. Therefore, DEET must remain on the skin surface, instead of getting absorbed into the skin, to ensure ideal activity. However, DEET can easily permeate through the skin and can enter the systemic circulation owing to its low molecular weight [(MW), 191.27 Da] and a favorable octanol/water partition coefficient ( $\log P$ ) of 2.1. Generally, compounds having MW $<500$ Da and log $P$ values in the range of 1-3 can easily permeate through the skin. Such compounds are considered ideal for transdermal delivery. ${ }^{2}$ Although DEET is considered to be safe for humans, but its entry into the systemic circulation is unnecessary. Moreover, most of the commercially available DEET preparations provide protection for only 1-4 hours, probably due to its rapid absorption by the skin. Topical application of polymeric microparticles on the skin allows slow release of the encapsulated active drugs, which can further prolong the therapeutic effect of the drug. In addition to this, the large size of microparticles might impede the rapid skin permeation, reducing any unwanted effects. ${ }^{3}$ Currently, various strategies involving the use of formulations, like liposomes and microparticles, are being explored to address the issue of dermal absorption of DEET. ${ }^{4}$ The present study aimed to develop a chitosan-based biocompatible microparticle formulation of DEET to allow controlled release of the drug. Chitosan microparticles have been shown to offer several advantages such as biocompatibility, enhanced stability, and a simple production process devoid of any requirement for organic solvents or high temperature.5,6 DEET microparticle formulations were incorporated into a hydrogel base and rheological evaluations were performed. Rheological studies are very important for the evaluation of newly synthesized topical formulations; however, these measurements are mostly limited to viscosity determination. An ideal gel must be thixotropic i.e., when a gel formulation is applied onto the skin it should easily transform into a sol consistency, and post application it should regain its original gel form. Thixotropic property of gel allows the formulation to spread easily onto the skin surface, such that it will remain on the skin for a sufficient duration and exert its therapeutic effect. Previous studies have reported that particles with size $>300 \mathrm{~nm}$ are unable to penetrate through the stratum corneum, the outermost layer of the skin. ${ }^{7}$ Chitosan-based nanoparticles or microparticles have been shown to allow a controlled release of the encapsulated contents assisted by the slow erosion of the polymer. ${ }^{8}$ In the present study, DEET encapsulated chitosan microparticles were synthesized to achieve a controlled release of DEET while ensuring lower skin permeation. These chitosan-based microparticles were further assessed for their rheological properties, in vitro drug release, and permeation ability. Factorial design was employed to obtain an appropriate mathematical model for optimizing the composition of the formulation.

\section{MATERIALS AND METHODS}

\section{Materials}

DEET, chitosan (low MW), and sodium tripolyphosphate (TPP) were purchased from Sigma-Aldrich, USA. Strat-M ${ }^{\circledR}$ was procured from Merck Millipore, Germany. Acetic acid and triethanolamine were obtained from Chemiz (M) Sdn. Bhd., Malaysia. Methanol high performance liquid chromatography [(HPLC) grade] was purchased from Fisher Scientific, UK. Other chemicals used in the study were of analytical grade.

\section{Methodology}

\section{Formulation of DEET containing microparticles}

DEET-loaded chitosan microparticles were prepared using ionic gelation method. ${ }^{9}$ Chitosan $(0.4 \% \mathrm{w} / \mathrm{v})$ solution was prepared in dilute acetic acid (2\%v/v). The solution was stirred at 500-1000 rpm using a magnetic stirrer to ensure complete dissolution of chitosan. The $\mathrm{pH}$ of chitosan solution was adjusted to 5.0 and $1 \mathrm{mg}$ of DEET was added to this solution. This was followed by dropwise addition of the cross-linker TPP $(0.1 \% \mathrm{w} / \mathrm{v})$, with continuous stirring at $700 \mathrm{rpm}$. To remove excess reagents, the micro-particulate suspension was centrifuged at $6000 \mathrm{rpm}$ for 30 mins.

Optimization of formulation by factorial design using designexpert software

The complexity in the pharmaceutical formulations are evaluated using established tools like factorial design. ${ }^{9}$ The present study was based on independent formulation variables, selected using simple two-level factorial designs of experiments. ${ }^{2}$ Design-expert software version 11 (Stat-Ease. Inc) was used to design the experimental runs. Two-level factorial design and three variables (factors) were applied, with a minimum of 5 runs. For analysis, chitosan and TPP concentrations were used as variable (independent), while particle size, encapsulation efficiency (EE), and drug release of the developed formulation were used as the dependant factor. Further, $2 \times 2$ factorial design and statistical design of the responses were applied to the optimized formulations. 
Development and validation of HPLC method for DEET analysis

A simple and economical method based on reversed-phase HPLC (RP-HPLC) was employed for accurate quantification of DEET present in the microparticles. HPLC system (Perkin Elmer, USA) equipped with an auto-injector, a quaternary pump, and a diode array detector was used. HPLC analysis was performed on a reversed-phase column (Hypersil Gold C18, 5 $\mu \mathrm{m}, 250 \mathrm{~mm} \times 4.6 \mathrm{~mm}$ ) maintained at $25^{\circ} \mathrm{C}$ with a mobile phase comprising of methanol:water (70:30) at a flow rate of $1.2 \mathrm{~mL} /$ $\mathrm{min}$. For DEET detection, the wavelength was set at $210 \mathrm{~nm}$. The retention time of DEET was found to be 6.1 minutes.

\section{Fourier-transform infrared spectroscopy (FTIR) analysis}

The drug-excipient compatibility studies were performed using attenuated total reflectance-FTIR [(ATR)-FTIR, Thermo Fisher Scientific, USA] over the range of $400-4000 \mathrm{~cm}^{-11} .^{10} \mathrm{FTIR}$ plays an important role in pre-formulation phase of drug development and provides information regarding any possible interactions between active drug and used additives. FTIR spectra of DEET, TPP, chitosan, and the DEET microparticles loaded hydrogel were recorded using ATR-FTIR spectrophotometer equipped with OMNIC software version 9.2.

\section{Particle size and surface morphology analyses}

The particle size analysis was performed using Zeta sizer $\mathrm{Nano}^{\circledR}$ (Malvern Instruments, Malvern, UK). For measurement, the suspension was diluted using deionized water." Surface morphology of the microparticles was analyzed using a field emission-scanning electron microscope [(FE-SEM), Quanta $400 \mathrm{~F}, \mathrm{FEI}, \mathrm{USA}]$ at a voltage of $5 \mathrm{kV}$. For sample preparation, the microparticle suspension was placed on a double-sided carbon tape, mounted onto an imaging stub, and allowed to dry overnight at room temperature.

\section{Encapsulation efficiency}

The EE of the formulation was determined using the centrifugation technique. The drug-loaded microparticle suspension was centrifuged at $6000 \mathrm{rpm}$ for 30 mins. The supernatant was collected in a separate tube and filtered using a nylon syringe filter $(0.45 \mu \mathrm{m})$. The drug content in the supernatant, representing the unencapsulated drug, was analyzed using HPLC. The EE was calculated using below mentioned formula. ${ }^{2}$

$\% \mathrm{EE}=\frac{\text { Total amount of drug added to the formulation-Unencapsulated drug }}{\text { Total amount of drug added to the formulation }} \times 100$

\section{In vitro drug release studies for DEET microparticles}

Drug release from the microparticles was determined by dialysis bag method.13 The formulation was re-dispersed in phosphate buffered saline (PBS) at $\mathrm{pH} 5.0$ and placed in a dialysis bag (MWCO $14000 \mathrm{Da})$. Both ends of the bag were tied and it was placed in a bottle containing PBS maintained at $37^{\circ} \mathrm{C}$ with continuous stirring at $100 \mathrm{rpm}$. At predetermined time intervals, the release medium was removed and replaced with an equal volume of fresh buffer. The amount of drug present in the release medium was quantified using HPLC. Various zero and first order kinetic models, like Higuchi, Korsmeyer-Peppas, and the Hixson-Crowell model, were used to evaluate the drug release mechanism of DEET microparticles. ${ }^{14}$

Formulation of microparticles loaded hydrogel and its rheological evaluation

A hydrogel was prepared by dissolving Carbopol 940 (1\% w/v) in purified water. After $24 \mathrm{~h}$ of swelling, triethanolamine was added to the hydrogel to adjust the $\mathrm{pH}$ to 5.0 and achieve the desired consistency. ${ }^{15}$ DEET microparticles were added to the gel and mixed continuously using a magnetic stirrer to obtain homogeneous preparation. Rheological studies for viscosity and thixotropy measurements were performed using Thermo Haake Rheometer (Thermo Fisher Scientific, USA). Commercially available DEET cream formulation was used as control.16,17 The data were analyzed using various rheological models, such as Bingham, Casson, and Herschel-Bulkey model. ${ }^{18}$

\section{In vitro permeation of DEET across synthetic Strat-M ${ }^{\circledR}$ membrane}

In vitro permeation of the formulation was performed using synthetic Strat-M ${ }^{\circledR}$ membrane. ${ }^{19}$ Static Franz diffusion cells having donor and receptor capacities of approximately 1 and 2 $\mathrm{mL}$, respectively, were used for the permeation experiments. Strat- $M^{\circledast}$ membrane was placed between the donor and receptor compartment. The formulation was loaded into the donor compartment, while the receptor compartment was filled with PBS at pH 7.4. The solution in the receptor compartment was stirred continuously using a magnetic stirring rod. The samples were collected from the receptor compartments at predetermined time points up to 24 hours and immediately replaced with equal volume of fresh receptor medium. ${ }^{20}$ To generate permeation profile curves, the cumulative amount of drug permeated $\left(\mu \mathrm{g} / \mathrm{cm}^{2}\right)$ was plotted as a function of time. The steady state flux $(\mathrm{J})$, representing the amount of drug permeated per unit area, was determined from the linear plot. ${ }^{21}$

\section{Statistical analysis}

Statistical analyses were performed using Graphpad Prism 7 software. Student's t-test was used to evaluate statistical significance between two groups. For more number of groups, statistical analysis involved One-Way ANOVA and post-hoc Tukey-honestly significant difference. P $<0.05$ was considered to be statistically significant.

\section{RESULTS AND DISCUSSION}

Optimization of microparticle preparation using design expert software

Design expert software was used to design the experiments for optimizing microparticle formulations. ${ }^{22}$ To study the significance of the concentration of chitosan and TPP in the development of DEET microparticles, three responses including particle size, entrapment efficiency, and drug release were considered. In the present study, two factorial design and statistical design of the responses were applied to the optimized formulations. Statistical design was considered to be significant for $p<0.05$. The two factorial design showed that the optimized formulations were characterized by two concentrations i.e., 
low and high concentrations. Statistical analysis for three responses was performed and it was characterized by two coefficients, positive and negative. The positive response indicated an increase in the parameters (particle size, entrapment efficiency, and drug release). In comparison to this, the negative sign suggested a decrease in the parameters. Chitosan and TPP were considered as two factors, while their concentrations represented two levels. The statistical analysis suggested that chitosan and TPP concentrations had no significant effect on the particle size and entrapment efficiency ( $p>0.05$ ), for the selected concentrations. However, chitosan and TPP concentrations showed significant effect on drug release of DEET microparticles $(p=0.038$ ) (Figure 1). Therefore, the release of DEET from the microparticles, developed using ionic gelation technique, could be modulated by changing the concentration of chitosan and TPP.

\section{Particle size and surface morphology analyses}

DEET microparticles, prepared using different ratios of chitosan: TPP, were characterized by an average particle size of 0.45-8.3 um (Table 1). Among five formulations, DM-3 (chitosan: TPP, 4:1) showed the lowest polydispersity index (PDI) $<0.5$ and average particle size of $0.45 \mu \mathrm{m}$. Thus, it was selected as the optimized formulation. Previous studies have reported that the particles with size $>300 \mathrm{~nm}$ pose difficulty in permeating through the skin. ${ }^{7}$ FE-SEM analysis of the optimized formulation showed that the microparticles were spherical in shape with smooth surface (Figure 2). In addition to this, the microparticles were sufficiently separated and showed no signs of aggregation, indicating physical stability of the formulation.

\section{Encapsulation efficiency}

The EE of the formulations varied in terms of the concentration of chitosan and TPP. The formulations DM-1, DM-2, DM-3, DM-
4, and DM-5 showed EE of $57.56 \pm 0.41,55.79 \pm 0.53,50.07 \pm 2.09$, $56.64 \pm 1.32$, and $57.34 \pm 0.34 \%$, respectively. The highest EE was observed for the formulation DM-1. This was possibly attributed to high proportion of chitosan and TPP, which would have further resulted in strong electrostatic interactions between the molecules. ${ }^{22}$ The availability of larger number of amino groups at higher concentrations of chitosan results in a decrease in the intermolecular distance and increase in the cross-linking density. ${ }^{6}$

\section{FTIR analysis}

As shown in Figure 3, the spectrum for DEET showed two bands at $2971.27 \mathrm{~cm}^{-1}$ and $2933.59 \mathrm{~cm}^{-1}$ corresponding to $\mathrm{CH}_{3}$ asymmetric stretch and symmetric stretch, respectively. The band present at $1626.39 \mathrm{~cm}^{-1}$ might be contributed by $\mathrm{C}=\mathrm{O}$ stretching of the amide bond. ${ }^{23}$ The peak at $1583.77 \mathrm{~cm}^{-1}$ was contributed by $\mathrm{C}-\mathrm{C}$ stretching of aromatic ring. The presence of $\mathrm{C}-\mathrm{C}$ stretching was observed at $1427.59 \mathrm{~cm}^{-1}{ }^{24}$ In case of chitosan, the peak at $3354.85 \mathrm{~cm}^{-1}$ was contributed by- $\mathrm{NH}$ stretching vibration. The band at $2875.90 \mathrm{~cm}^{-1}$ represented $\mathrm{CH}$

\begin{tabular}{|c|c|c|c|}
\hline $\begin{array}{l}\text { Formulation } \\
\text { code }\end{array}$ & $\begin{array}{l}\text { Chitosan:TPP } \\
\text { (mass ratio) }\end{array}$ & $\begin{array}{l}\text { Average particle } \\
\text { size }(\mathrm{nm})\end{array}$ & PDI \\
\hline DM-1 & $4: 4$ & $8258.7 \pm 366.3$ & 0.70 \\
\hline DM-2 & $1: 4$ & $6525.7 \pm 182.7$ & 0.73 \\
\hline DM-3 & $4: 1$ & $446.5 \pm 18.6$ & 0.50 \\
\hline DM-4 & $1: 1$ & $4950 \pm 172.5$ & 0.80 \\
\hline DM-5 & $2.5: 2.5$ & $5385.7 \pm 129.1$ & 0.79 \\
\hline
\end{tabular}

DEET: N,N-Diethyl-3-methylbenzamide, TPP: Tripolyphosphate, PDI: Polydispersity index
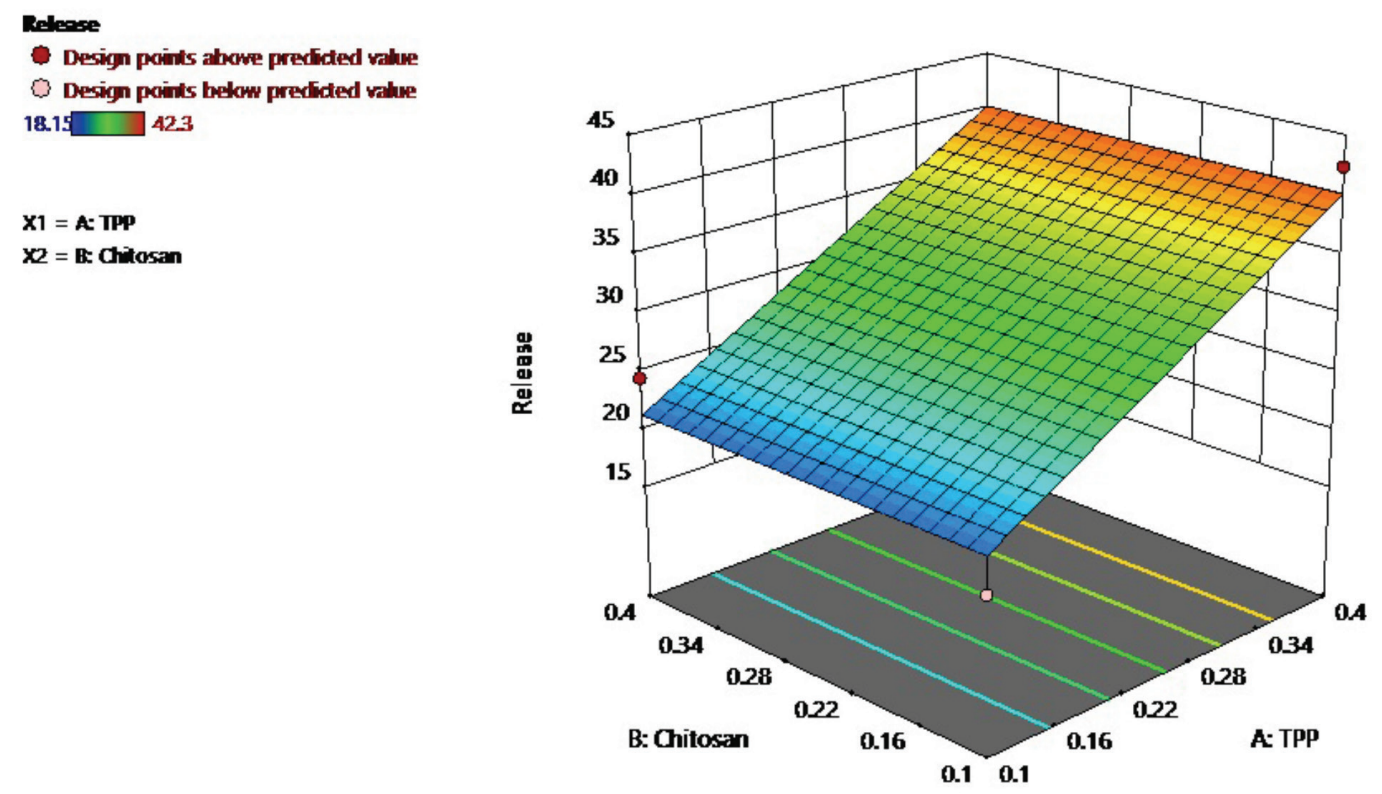

Figure 1. Contour plot (phase diagram) for drug release from the developed DEET microparticles

DEET: N,N-Diethyl-3-methylbenzamide 


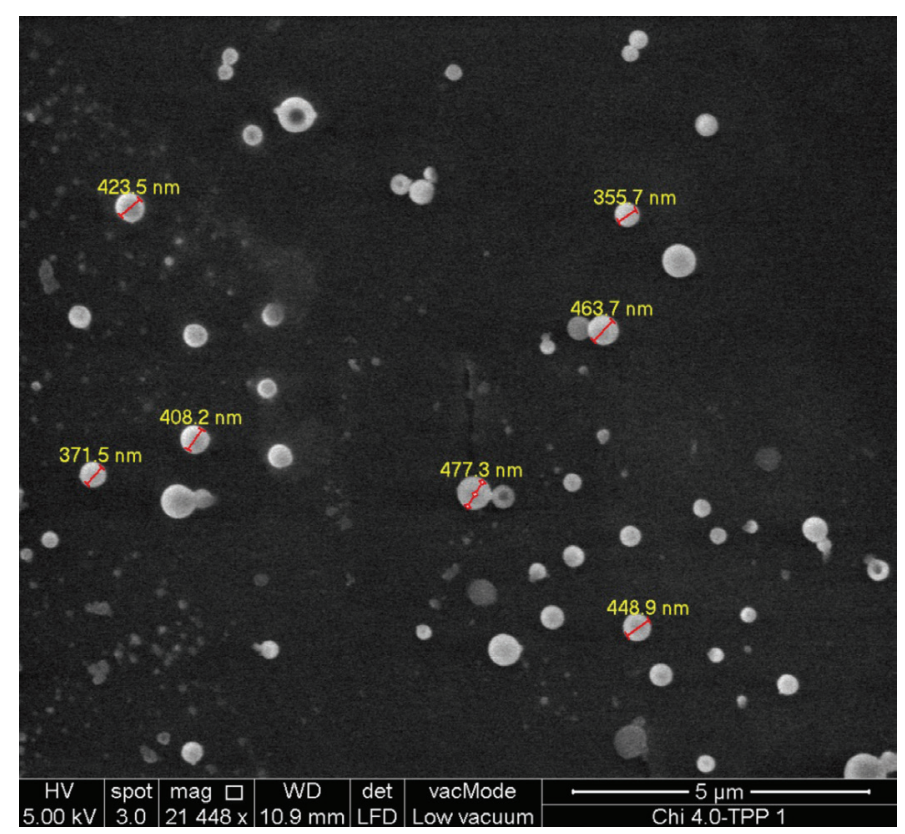

Figure 2. FE-SEM image of optimised polymeric DEET microparticles (chitosan:TPP mass ratio of 4:1)

FE-SEM: Field emission-scanning electron microscope, DEET: N,N-Diethyl-3methylbenzamide, TPP: Tripolyphosphate stretching and band at $1645.99 \mathrm{~cm}^{-1}$ indicated $\mathrm{C}=\mathrm{O}$ (carbonyl) corresponding to the amide group from-CONH. In addition to this, a band corresponding to amine $\left(\mathrm{NH}_{2}\right)$ group was also observed seen at $1588.73 \mathrm{~cm}^{-1}$. TPP showed two characteristic peaks at 1209.59 and $1136.47 \mathrm{~cm}^{-1}$ corresponding to phosphate $(P=O)$ symmetric and anti-symmetric stretching vibrations $(\mathrm{O}-\mathrm{P}=\mathrm{O})$, respectively. Similar peaks were recorded for chitosan-TPP microparticles, indicating no incompatibility between DEET and the excipients used.

\section{In vitro drug release}

The drug release curves for DEET microparticles showed that there was no initial burst release of the drug from the formulation. Instead, a slow and controlled drug release was observed over time (Figure 4). This might be attributed to homogenous encapsulation of DEET into the microparticles, which was supported by the low PDI value of $<0.5$. In general, the microparticles with poor encapsulation are characterized by drug deposition on the surface that might result in initial burst release of the drug. Besides this, the concentration of TPP might also have some effect on drug release from microparticles. In the present study, the formulation DM-1 showed a lower drug release $(38.03 \% \pm 1.97 \%)$ as compared to the formulation DM-3 $(42.30 \% \pm 4.84 \%)$, over a period of 24 hour. This might be contributed by higher TPP content of

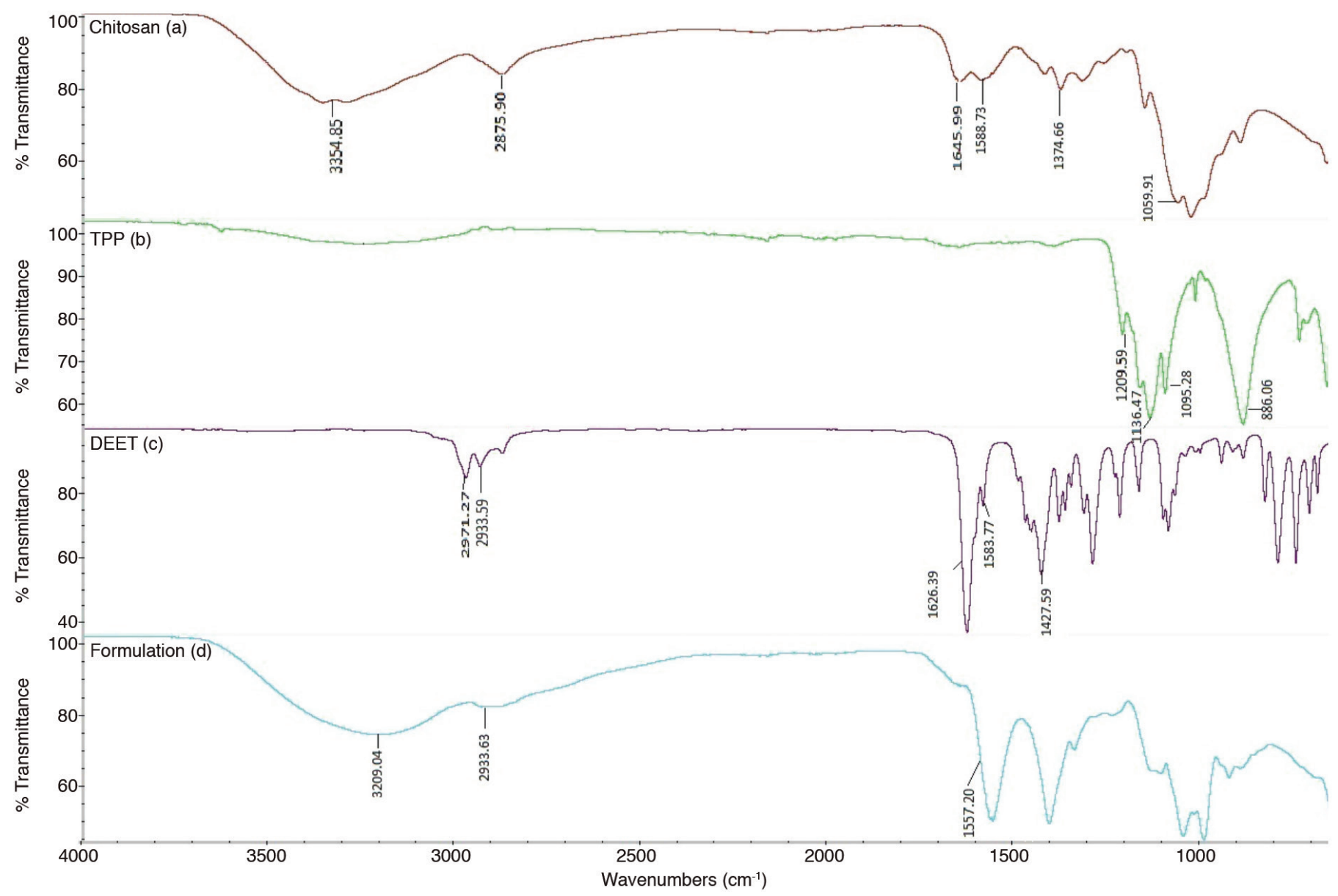

Figure 3. FTIR spectrum for (a) chitosan, (b) TPP, (c) DEET, and (d) formulation

FTIR: Fourier-transform infrared spectroscopy, DEET: N,N-Diethyl-3-methylbenzamide, TPP: Tripolyphosphate 
DM-1 as compared to DM-3. The drug release from chitosanTPP microparticles was found to decrease with an increase in the concentration of crosslinking agent (TPP). ${ }^{8}$ Several studies have previously reported that smaller microparticles exhibit larger surface area, resulting in faster swelling and drug release. Chitosan has been previously shown to absorb the release medium, that assists in the swelling and penetration of the medium inside the polymer matrix. ${ }^{25}$ The drug release from the microparticles might be attributed to diffusion of the drug through the swollen polymer. Higuchi model correlation coefficient provided best fit with $R^{2}$ value 0.9586 . This suggested involvement of a diffusion mechanism wherein the drug diffuses constantly from the polymer matrix while maintaining a perfect sink condition. ${ }^{26,27}$

\section{In vitro permeation of DEET across synthetic Strat-M ${ }^{\circledR}$ membrane}

In vitro permeation experiments were performed using Static Franz diffusion cells with synthetic Strat- $\mathrm{M}^{\circledR}$ membrane placed between the donor and receptor compartments. Strat- $\mathrm{M}^{\circledR}$ membrane is widely used for the permeation studies and the obtained results have been shown to be comparable to the human skin. ${ }^{28}$ Strat- $\mathrm{M}^{\circledR}$ comprises of two layers of polyether sulfone, followed by one layer of porous polyolefin. In addition to its close similarity with the skin, Strat-M ${ }^{\circledR}$ usage is devoid of any special requirements of storage and safety, that are usually associated with biological membranes. Permeation experiments were conducted for pure DEET solution (control) and the optimized formulation. Over a period of $24 \mathrm{~h}$, the cumulative amounts of DEET permeated from the control solution and DEET formulation were found to be $211.6 \pm 19.5 \mu \mathrm{g} /$ $\mathrm{cm}^{2}$ and $4.07 \pm 0.08 \mu \mathrm{g} / \mathrm{cm}^{2}$, respectively (Figure 5 ). A significant difference ( $p<0.05$ ) was observed between the cumulative drug permeation for the control and the formulation. Flux values of $9.61 \pm 0.94 \mu \mathrm{g} \mathrm{cm}^{-2} \mathrm{~h}^{-1}$ and $0.12 \pm 0.001 \mu \mathrm{g} \mathrm{cm}^{-2} \mathrm{~h}^{-1}$ were recorded for the control DEET solution and microparticles loaded hydrogel, respectively. The flux of the optimized formulation was significantly lower as compared to the control $(p<0.05)$. All these results showed that the formulation allowed minimal permeation of the drug into the skin, thereby ensuring a possible reduction in the systemic toxicity.

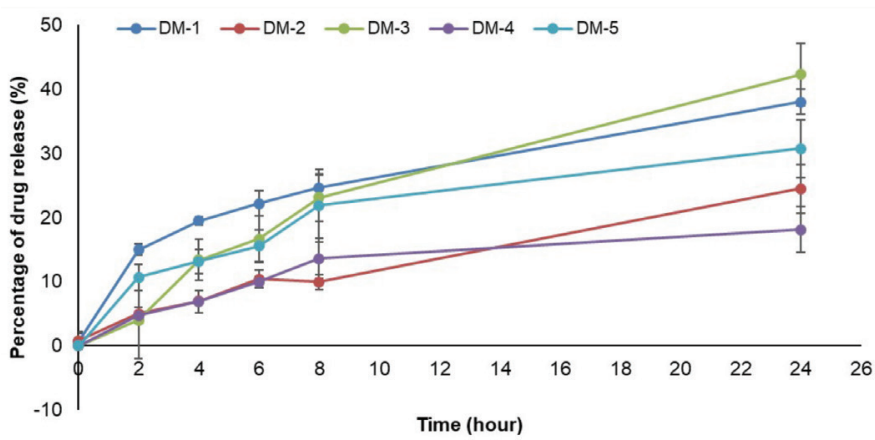

Figure 4. Profile for drug release from DEET microparticles (chitosan:TPP mass ratio of 4:1) at $\mathrm{pH} 7.4$. Mean $\pm \mathrm{SD},(n=3)$

DEET: N,N-Diethyl-3-methylbenzamide, TPP: Tripolyphosphate, SD: Standard deviation

\section{Rheological studies of the formulation}

As shown in Figure 6, a hysteresis loop demonstrated the thixotropic behavior of the hydrogel (Figure 6). The intrinsic mechanism contributing to thixotropic behavior of the gel was based on the three-dimensional structure of the molecules that were capable of forming hydrogen bonds. When a shearing stress was applied, reduction in these interactions resulted in a decrease in viscosity, turning the gel into a sol state (ascending curve). Post the removal of shearing stress, the gel regained its conformation slowly (descending curve). The restructuring of bonds between the molecules was attributed to Brownian motion of the molecules, which could be linked to the amount of shear stress applied..$^{18}$ It is important to evaluate the thixotropic property of a semisolid preparation, designed for topical application, as it reflects the ease of application of the product on the skin. The sol form of the product allows effortless application on the skin. Once the shear stress is removed, the product regains its initial gel conformation, which is better retained on the skin. The best-fit rheological model was determined by assessing $R^{2}$ values. All the samples followed Herschel-Bulkley model. The rheological parameters corresponding to the Herschel-Bulkey model are summarized in Table 2. Yield stress is the minimum stress required to induce the flow of a material. It is an important factor used for the characterization of semisolid preparation. It usually affects the spreadability and retention of the formulations. High value of yield stress demonstrates a reduction in the spreadability and enhancement in the retention capacity of the preparation, and vice-versa. ${ }^{29}$ In the present study, the yield stress for the formulation and control DEETcream were found to be 26.39 and $6.474 \mathrm{~Pa}$, respectively. This indicated that the standard cream was more spreadable as compared to the optimized formulation. Substantial yield strength was required to break the microgel network present in the hydrogel, thus contributing to the higher yield stress observed for the hydrogel as compared to the cream. ${ }^{16}$ Degree of shear thinning behavior of semisolid preparations can be analyzed by looking

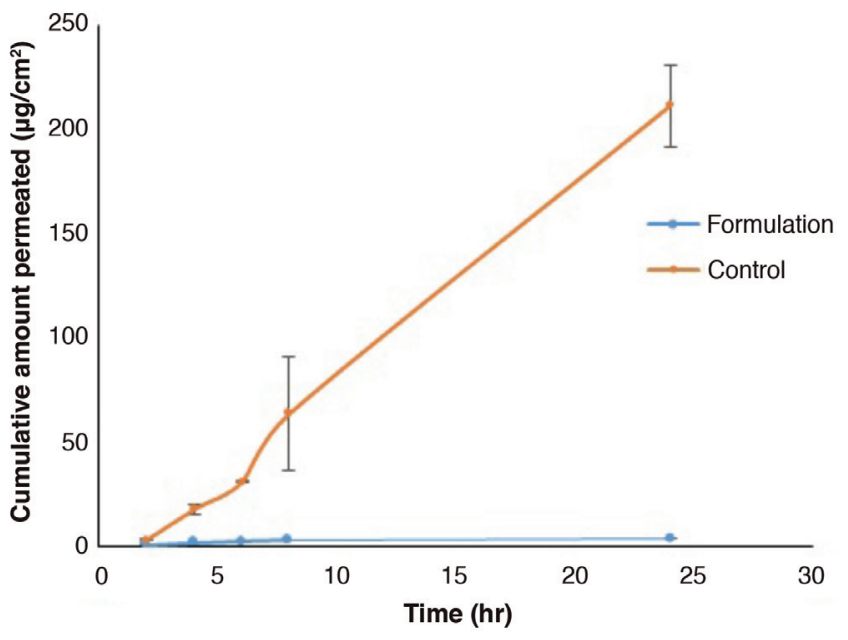

Figure 5. Cumulative amount of DEET permeated $\mu \mathrm{g} / \mathrm{cm}^{2}$ over time ( $\mathrm{hr}$ ) for control (DEET solution) and the formulation. Mean $\pm \mathrm{SD},(n=3)$

DEET: N,N-Diethyl-3-methylbenzamide, SD: Standard deviation 


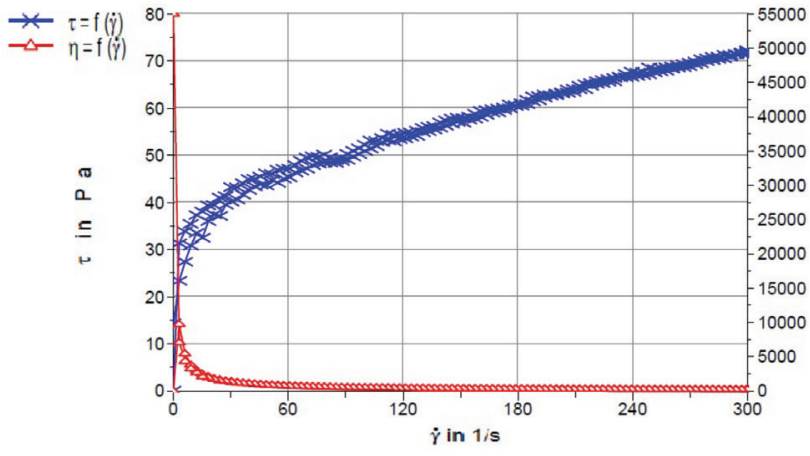

Figure 6. Rheogram of the hydrogel formulation containing DEET mocroparticles showing thixotropic behaviour

DEET: N,N-Diethyl-3-methylbenzamide

Table 2. Rheological parameters corresponding to the

Herschel-Bulkey model for the standard cream, and the formulation

\begin{tabular}{lll} 
Formulations & $\begin{array}{l}\text { Yield stress } \\
(\mathrm{Pa})\end{array}$ & Flow index $(\mathrm{n})$ \\
\hline Standard cream & $6.47 \pm 1.37$ & $0.275 \pm 0.01$ \\
\hline Hydrogel formulation & $26.39 \pm 4.9$ & $0.791 \pm 0.26$ \\
\hline
\end{tabular}

at the flow index values, $n$. In the present study, all the samples were characterized by $n<1$. These results suggested that all the samples exhibited a non-Newtonian pseudoplastic behavior. ${ }^{30}$

\section{CONCLUSION}

DEET microparticles loaded hydrogel was successfully formulated and evaluated in vitro. The formulation permitted topical delivery of DEET with controlled drug release, which followed Higuchi kinetic model. The rheological evaluations demonstrated the suitability of the hydrogel for topical application. Ease of application and prolonged drug retention on the skin balanced with high cosmetic acceptability, highlighted the utility of this gel as a promising drug carrier. In vitro drug permeation studies provided evidence for low permeation of DEET from the hydrogel as compared to the control. Thus, all these results suggested that DEET microparticle loaded hydrogel could be used as an effective strategy to ensure controlled and effective insect repellent activity of DEET. Future studies focusing on ex vivo and in vivo evaluation of this formulation are required to support these preliminary findings.

\section{ACKNOWLEDGMENTS}

The authors would like to acknowledge the Faculty of Pharmaceutical Sciences, UCSI University, Kuala Lumpur for providing the financial support for this project.

Conflicts of interest: No conflict of interest was declared by the authors. The authors alone are responsible for the content and writing of the paper.

\section{REFERENCES}

1. Fei $\mathrm{B}, \mathrm{Xin} \mathrm{JH}$. N. N-diethyl-m-toluamide-containing microcapsules for bio-cloth finishing. Am J Trop Med Hyg. 2007;77:52-57.

2. Chandrashekar NS, Rani RS. Physicochemical and pharmacokinetic parameters in drug selection and loading for transdermal drug delivery. Indian J Pharm Sci. 2008;70:94.

3. Tavares M, da Silva MR, de Siqueira LB, Rodrigues RA, Bodjolled'Almeida L, Dos Santos EP, Ricci-Júnior E. Trends in insect repellent formulations: A review. Int J Pharm. 2018;539:190-209.

4. Karr JI, Speaker TJ, Kasting GB. A novel encapsulation of N, N-diethyl-3methylbenzamide (DEET) favorably modifies skin absorption while maintaining effective evaporation rates. J Control Release. 2012;160:502-508.

5. Calvo P, Remunan-Lopez C, Vila-Jato JL, Alonso MJ. Novel hydrophilic chitosan-polyethylene oxide nanoparticles as protein carriers. J Appl Polym Sci. 1997;63:125-132.

6. Fan W, Yan W, Xu Z, Ni H. Formation mechanism of monodisperse, low molecular weight chitosan nanoparticles by ionic gelation technique. Colloids Surf B Biointerfaces. 2012;90:21-27.

7. Campbell CS, Contreras-Rojas LR, Delgado-Charro MB, Guy RH. Objective assessment of nanoparticle disposition in mammalian skin after topical exposure. J Control Release. 2012;162:201-207.

8. Ko JA, Park HJ, Hwang SJ, Park JB, Lee JS. Preparation and characterization of chitosan microparticles intended for controlled drug delivery. Int J Pharm. 2002;249:165-174.

9. de Pinho Neves AL, Milioli CC, Müller L, Riella HG, Kuhnen NC, Stulzer HK. Factorial design as tool in chitosan nanoparticles development by ionic gelation technique. Colloids Surf A Physicochem Eng Asp. 2014;445:3439

10. Shu XZ, Zhu KJ. The influence of multivalent phosphate structure on the properties of ionically cross-linked chitosan films for controlled drug release. Eur J Pharm Biopharm. 2002;54:235-243.

11. Liu CG, Chen XG, Park HJ. Self-assembled nanoparticles based on linoleic-acid modified chitosan: Stability and adsorption of trypsin. Carbohydr Polym. 2005;62:293-298.

12. Chuah LH, Billa N, Roberts CJ, Burley JC, Manickam S. Curcumincontaining chitosan nanoparticles as a potential mucoadhesive delivery system to the colon. Pharm Dev Technol. 2013;18:591-599.

13. D'Souza S. A review of in vitro drug release test methods for nano-sized dosage forms. Adv Pharm. 2014;2014:1-12.

14. Katas $\mathrm{H}$, Hussain $\mathrm{Z}$, Ling TC. Chitosan nanoparticles as a percutaneous drug delivery system for hydrocortisone. J Nanomater. 2012;2012:1-11.

15. Berdey II, Voyt Ol. Rheological properties of emulgel formulations based on different gelling agent. J Pharm Innov. 2016;5:76-79.

16. Islam MT, Rodriguez-Hornedo N, Ciotti S, Ackermann C. Rheological characterization of topical carbomer gels neutralized to different $\mathrm{pH}$. Pharm Res. 2004:21:1192-1199.

17. Martínez-Ruvalcaba A, Chornet E, Rodrigue D. Viscoelastic properties of dispersed chitosan/xanthan hydrogels. Carbohydr Polym. 2007;67:586595.

18. Ortan A, Parvu CD, Ghica MV, Popescu LM, lonita L. Rheological study of a liposomal hydrogel based on carbopol. Rom Biotech Lett. 2011;16:4754.

19. Sreedharan Nair R, Nair S. Permeation studies of captopril transdermal films through human cadaver skin. Curr Drug Deliv. 2015;12:517-523. 
20. Singh I, Nair RS, Gan S, Cheong V, Morris A. An evaluation of crude palm oil (CPO) and tocotrienol rich fraction (TRF) of palm oil as percutaneous permeation enhancers using full-thickness human skin. Pharm Dev Technol. 2019;24:448-454.

21. Mustapha RB, Lafforgue C, Fenina N, Marty JP. Influence of drug concentration on the diffusion parameters of caffeine. Indian $\mathrm{J}$ Pharmacol. 2011;43:157.

22. Chen KY, Zeng SY. Fabrication of quaternized chitosan nanoparticles using tripolyphosphate/genipin dual cross-linkers as a protein delivery system. Polymers (Basel). 2018;10:1226.

23. Inceboz T, Erkan G, Türkoğlu GC, Sarışık AM, Bakırcı S, Üner S, Üner A. In-vivo and in-vitro tick repellent properties of cotton fabric. Text Res J. 2015;85:2071-2082.

24. Bonadies I, Longo A, Androsch R, Jehnichen D, Göbel M, Di Lorenzo $\mathrm{ML}$. Biodegradable electrospun PLLA fibers containing the mosquitorepellent DEET. Eur Polym J. 2019;113:377-384.

25. Nair RS, Morris A, Billa N, Leong CO. An evaluation of curcuminencapsulated chitosan nanoparticles for transdermal delivery. AAPS PharmSciTech. 2019;20:69.
26. Abdel Bary EM, Harmal AN, Saeed A, Gouda MA. Design, synthesis, characterization, swelling and in vitro drug release behavior of composite hydrogel beads based on methotrexate and chitosan incorporating antipyrine moiety. Polym Plast Technol. 2018;57:1906-1914.

27. Gouda R, Baishya H, Qing Z. Application of mathematical models in drug release kinetics of carbidopa and levodopa ER tablets. J Develop Drugs. 2017;6:2.

28. Haq A, Dorrani M, Goodyear B, Joshi V, Michniak-Kohn B. Membrane properties for permeability testing: Skin versus synthetic membranes. Int J Pharm. 2018;539:58-64.

29. Dash M, Chiellini F, Ottenbrite RM, Chiellini E. Chitosan-A versatile semisynthetic polymer in biomedical applications. Prog Polym. 2011;36:9811014.

30. Vigilato MÁ, Horn M, Martins VC, de Guzzi Plepis AM. Rheological study of gels based on chitosan and carbon nanotubes. Braz J Therm Anal. 2015;4:35-38. 